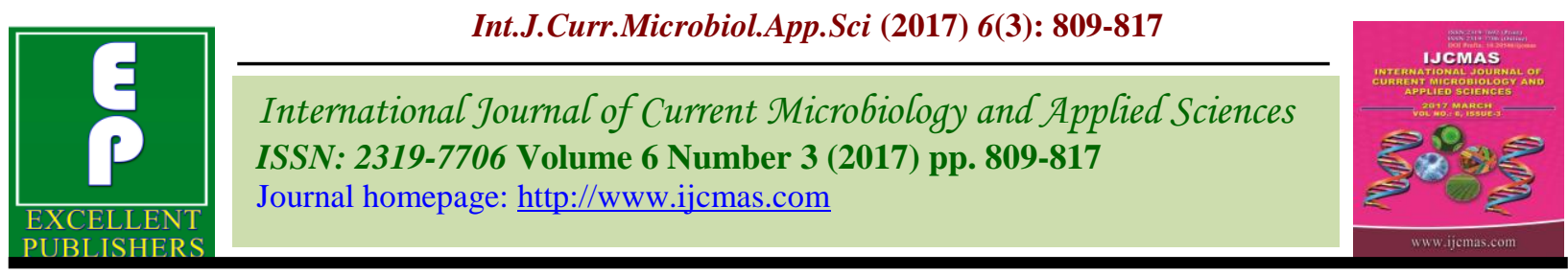

Original Research Article

https://doi.org/10.20546/ijcmas.2017.603.095

\title{
Quantification of Energy Indices Requirement of Cotton Varieties under Different Growing Environments
}

\author{
Premdeep*, Ram Niwas, M.L. Khichar, Abhilash and Abhijeet Sharma \\ Department of Agricultural Meteorology, CCS Haryana Agricultural University, \\ Hisar-125004, India \\ *Corresponding author
}

\begin{tabular}{|c|c|}
\hline & A B S T R A C T \\
\hline Kovwords & A field experiment was conducted at research area of Department of Agricultural \\
\hline Keyworas & $\begin{array}{l}\text { Meteorology, CCS Haryana Agricultural University, Hisar, during the kharif season of } \\
2013-14 \text {. The main plots treatments consisted of four date of sowing }\left(2^{\text {nd }} \text { week of April, } 4^{\text {th }}\right.\end{array}$ \\
\hline $\begin{array}{l}\text { Sowing date, } \\
\text { Varieties and } \\
\text { indices use } \\
\text { efficiency, PAR. }\end{array}$ & $\begin{array}{l}\text { week of April, } 2^{\text {nd }} \text { week of May and } 1^{\text {st }} \text { week of June) and the sub-plots consisted of three } \\
\text { cotton varieties (HD 123, H } 1098 \text { and RASI 134). In the } 2^{\text {nd }} \text { week of April sown crop } \\
\text { consumed highest thermal and radiation indices, and efficiently converted the } \\
\text { thermal/radiant energy into biomass production. The transmitted photosynthetic ally active }\end{array}$ \\
\hline Article Info & $\begin{array}{l}\text { radiation was lowest in } G_{1} \text { followed by } G_{2}, G_{3} \text { and } G_{4} \text {. All growth parameters and yield } \\
\text { attributes were found highest in } 2^{\text {nd }} \text { week of April sown crop. Among cotton varieties, }\end{array}$ \\
\hline $\begin{array}{l}\text { Accepted: } \\
15 \text { February } 2017 \\
\text { Available Online: } \\
10 \text { March } 2017\end{array}$ & $\begin{array}{l}\text { RASI } 134 \text { consumed highest heat units, heliothermal units and photo thermal units as } \\
\text { compared to H } 1098 \text { and HD } 123 \text { under different growing environments. The efficiency of } \\
\text { PAR utilization for dry matter production was highest in RASI } 134 \text { during all } \\
\text { phenophases. The efficiency of heat utilization was also more in RASI } 134 \text { as compared to } \\
\text { H } 1098 \text { and HD } 123 \text { during all phenophases. }\end{array}$ \\
\hline
\end{tabular}

\section{Introduction}

Cotton is a one of the most important fiber crop in the world. It is also called as white gold. The primary product of the cotton plant has been the lint that covers the seeds within the boll. Important cotton producing states are Gujarat, Maharashtra, Tamil Nadu, Punjab and Haryana in India. Average area under cotton was 5.6 lakh hectares with an average production of 23 lakh bales and an average productivity of $691 \mathrm{~kg} /$ hectare in Haryana during 2013. Monga et al., (2009) studied radiation pattern in tomato crop under different sowing environments. Singh (1999) observed decline in thermal use efficiency with delayed sowing and explained that it was due to less biomass production and less heat unit accumulation in delayed sown crops. A heat unit is a measure of the amount of heat energy a plant accumulates each day during the growing season and has been used to describe the development of crops (Peng et al., 1989). A cotton plant can produce one open boll and four more bolls that are $85 \%$ mature with 1000 heat unit, and crop termination through defoliation at this stage of plant development results in a loss of about one per cent of total expected yield but does not reduce the fiber quality (Wrona et al., 1996). Singh et al., (2007) found that heat unit requirements of different genotypes of 
cotton increased with advancement of crop growth i.e. from germination to maturity. Kaur and Hundal (2006) also reported that the heat units accumulated were higher in early sown Brassica species as compared to middle and late sown crop. Brodick et al., (2013) reported increase in light interception with increase in leaf area index and both were higher in ultra-narrow row crops. Hence this study was undertaken to quantify the energy indices requirement of cotton variety under different growing environments of Haryana.

\section{Materials and Methods}

A field experiment was conducted at the Research Farm of the Department of Agricultural Meteorology, CCS Haryana Agricultural University, Hisar. It is situated in the semi arid zone at an elevation of $215 \mathrm{~m}$ with a longitude of $75^{\circ} 46^{\prime} \mathrm{E}$ and latitude of $29^{\circ} 10^{\prime} \mathrm{N}$. The main plots treatments consisted of four dates of sowing $G_{1}, G_{2}, G_{3}$ and $G_{4}$ and the sub-plots consisted of three varieties (HD 123, H 1098 and RASI 134). The forty eight treatment combinations were tested in split plot design to quantify the energy indices of cotton cultivars under different growing environments.

\section{Agrometeorological observations}

Quantum sensor was used to measure PAR after 30 days of sowing at 30 days interval during noon hours at top, middle and bottom of canopy. Pyr was used to measure global solar radiation at similar intervals. The reflected radiation was obtained by keeping the sensor inverted at $1 \mathrm{~m}$ above the crop canopy and the sensor was also kept on ground across the rows diagonally and randomly sites to get transmitted radiation at the ground.

\section{Energy/ heat indices}

Energy indices viz., heat unit, heliothermal unit, photothermal unit and thermal interception rate were computed using daily weather data. Cumulative heat units (HU) were determined by summing the daily mean temperature above base temperature and are expressed in ${ }^{\circ} \mathrm{C}$ day. This was calculated using the following formula.

$\mathrm{HU}=\square\left(\mathrm{T}_{\text {max. }}+\mathrm{T}_{\text {min. }}\right) / 2-\mathrm{T}_{\mathrm{b}}$

Where, $\mathrm{T}_{\max }=$ Daily maximum temperature $\left({ }^{\circ} \mathrm{C}\right), \mathrm{T}_{\min }=$ Daily minimum temperature $\left({ }^{\circ} \mathrm{C}\right)$ $\& \mathrm{~T}_{\mathrm{b}}=$ Minimum threshold/base temperature $\left(10^{\circ} \mathrm{C}, \mathrm{WMO}, 1996\right)$

Heliothermal unit (HTU) represents the product of heat unit and bright sunshine hours for a day and is expressed in ${ }^{\circ} \mathrm{C}$ day hour, sums of HTU for particular phenophases of interest were determined according to the equation

$\mathrm{HTU}=\square(\mathrm{HU} \times \mathrm{n})$,

Where, $n=$ Actual sunshine hours

Day and night is one of the basic factors controlling the period of vegetative growth in a photosensitive crop. Photothermal units (PTU) are product of heat units and maximum possible sunshine hours and are expressed in ${ }^{\circ} \mathrm{C}$ day hours. PTU was calculated using the following formula.

PTU $=\Sigma($ HU $x$ N), Where, $\mathrm{N}=$ Maximum possible sunshine hours or day length

\section{Intercepted photosynthetically active radiation (IPAR)}

Daily solar radiation was computed by the expression

$\mathrm{Rs}=\mathrm{Ra}(1-\mathrm{r})(\mathrm{a}+\mathrm{b}(\mathrm{n} / \mathrm{N})$

Where, Rs is solar radiation received at the surface of the earth $\left(\mathrm{cal} / \mathrm{cm}^{2}\right), \mathrm{Ra}$ is solar radiation received outside the atmosphere 
$\left(\mathrm{cal} / \mathrm{cm}^{2}\right)$ taken from Smithsonian tables corresponding to the latitude values of Hisar, $r$ is reflection coefficient $(0.25)$ for green vegetations, $\mathrm{a}$ and $\mathrm{b}$ are constants, $\mathrm{a}=0.256 ; \mathrm{b}$ $=0.56$ for Hisar, (Bishnoi et al., 1995). The PAR values were converted into $\mathrm{MJ} / \mathrm{m}^{2}$, daily IPAR was calculated using the following expression.

PAR $=$ Rs $\times 0.48$ (Oleson et al., 2000) \& IPAR $=$ PAR $\left(1-\mathrm{e}^{-\mathrm{kf}}\right)$ (Rosenthal and Gerik, 1991).

Where, $\mathrm{k}$ is extinction coefficient $=\ln (\mathrm{I} / \mathrm{Io}) / \mathrm{F}$ (Monsi and Saeki, 1953), F is cumulative leaf area index of foliage layer, Io is radiation energy at the top of the canopy, and I is radiation energy at a level inside the crop canopy.

\section{Thermal Interception Rate (TIR)}

Thermal interception rate is the multiplication of heat units with solar radiation intercepted by a plant. This was computed by the formula:

$\mathrm{TIR}=\Sigma(\mathrm{Rs} / \mathrm{n}) \mathrm{HU}$,

Where, TIR $=$ Thermal interception rate $\left({ }^{\circ} \mathrm{C}\right.$ day MJ/plant) \& $\mathrm{T}_{\mathrm{b}}=$ Base/ threshold temperature $\left(10^{\circ} \mathrm{C}\right)$.

The radiation use efficiency is a ratio of biological yield and the radiation intercepted. It can be expressed by the following formula:

Radiation use efficiency $($ RUE $)=$ Dry matter / Intercepted PAR

Thermal use efficiency is a ratio of dry matter and heat unit consumed by the crop. It can be represented by the following formula:

Thermal use efficiency $=$ Dry matter $/ \mathrm{HU}$ accumulated

\section{Results and Discussion}

\section{Optical characteristics}

The optical characteristics (Transmitted, Reflected and Absorbed PAR) of cotton varieties in four growing environments are presented in table 1 . The maximum reflection (7.5\%) was observed in $G_{1}$, followed by $G_{2}$ $(7.0 \%), \mathrm{G}_{3}(6.8 \%)$ and $\mathrm{G}_{4}(5.5 \%)$. The variety HD 123 showed maximum transmission of $14.7 \%$, followed by $\mathrm{H} 1098(10.4 \%)$ and RASI 134 (6.5\%). Higher absorption (88.4\%) was found in RASI 134 as compared to $\mathrm{H}$ 1098 (83.6\%) and HD 123 (79.9\%).

The minimum level of transmission and maximum absorption of PAR was recorded in RASI 134 and first sowing date $\left(\mathrm{G}_{1}\right)$, because of maximum LAI recorded in same treatments. Transmission (\%) was found to be higher in $G_{1}$ sown crop as compared to other sowing dates $G_{2}$ and $G_{3}, G_{4}$. This might be due to the lower leaf area index in late sown crop in comparison with early sown crop.

\section{Energy indices}

The various agrometerological energy based indices (HU, HTU, PTU, TIR and IPAR) were computed for different phenophases of cotton crop and thermal indices are depicted in figure 1, 2 and 3.

Cumulated thermal time was highest in $G_{1}$ followed by $G_{2}, G_{3}$ and $G_{4}$ growing environment at all phenological stages (Figure 1). These values recorded at physiological maturity were $3669.8,3647.0,3550.8$ and $3447.6{ }^{\circ} \mathrm{C}$ day for $\mathrm{G}_{1}, \mathrm{G}_{2}, \mathrm{G}_{3}$ and $\mathrm{G}_{4}$, respectively. RASI 134 accumulated highest number of heat units $\left(2630.6{ }^{\circ} \mathrm{C}\right.$ day $)$ followed by $\mathrm{H} 1098\left(2550.6{ }^{\circ} \mathrm{C}\right.$ day $)$ and HD 123 (2508.6 ${ }^{\circ} \mathrm{C}$ day) (Figure 1). The cotton crop sown on $G_{1}$ accumulated higher thermal units as compared to $\mathrm{G}_{2}, \mathrm{G}_{3}$ and $\mathrm{G}_{4}$ sown crop 
because early sown crop utilized took more days to mature as compared to late sown.

Cumulative HTU at physiological maturity was higher in first sown crop as compared to delayed sown (Figure 2). HTU values at physiological maturity were 25509.6, 24406.3, 24149.9 and $24464.4{ }^{\circ} \mathrm{C}$ day hour for $G_{1}, G_{2}, G_{3}$ and $G_{4}$ respectively. Among cotton varieties, RASI 134 accumulated higher amount of HTU with the value of $20470.8{ }^{\circ} \mathrm{C}$ day as compared to $\mathrm{H} 1098$ and HD 123.Accumulation of HTU in early sown crop was higher due to more growing days and longer days available in early sown as compared to later sown crops. RASI 134 consumed maximum HTU due to more growth duration as compared to other varieties. Photothermal units were higher in $\mathrm{G}_{1}$ followed by $\mathrm{G}_{2}, \mathrm{G}_{3}$ and $\mathrm{G}_{4}$ at all phenological stages (Figure 3). These values at physiological maturity were 50577.5, 49720.1, 49632.6 and 48641.2 ${ }^{\circ} \mathrm{C}$ day hours for $\mathrm{G}_{1}, \mathrm{G}_{2} \mathrm{G}_{3}$ and $\mathrm{G}_{4}$ respectively. RASI 134 accumulated higher PTU with the value $50345.3{ }^{\circ} \mathrm{C}$ day hour as compared to $\mathrm{H} 1098$ and HD 123.The decrease in PTU accumulation with delay in sowing was due to the fact that delayed sowing experienced shorter days in combination with lower temperature which caused early reproductive phase in late sown crops. In case of cultivars, RASI 134 consumed maximum heat unit as compared to H 1098 and HD 123 might be the fact that it took more time upto maturity. The accumulated IPAR (intercepted PAR) was highest in the $G_{1}$ sown crop, followed by $G_{2}$, $\mathrm{G}_{3}$ and $\mathrm{G}_{4}$ sown crop at all phenological stages (Figure 4). These values at physiological maturity were 10452.2, 9844.4, 9656.7 and $9530.0 \mathrm{MJ} \mathrm{m}^{-2}$ for $\mathrm{G}_{1}, \mathrm{G}_{2}, \mathrm{G}_{3}$ and $\mathrm{G}_{4}$, respectively. Cultivar RASI 134 intercepted maximum PAR with value of 10053.7MJ m $\mathrm{m}^{-2}$ followed by $\mathrm{H} 1098$ and HD 123. The decrease in IPAR values with delay in sowing was due to reduction in leaf area index with delayed sowing. Thermal interception rate at different phenophases of cotton cultivars under different growing environments was worked out and is depicted in figure 5. TIR at physiological maturity was higher in first sown crop as compared to late sown cotton crops, thermal interception rate values were highest in G1 followed by G2, G3 and G4 sown crop at all phenological stages, the corresponding values were 113.4, 112.7, 110.7 and $103.5^{\circ} \mathrm{C}$ day MJ/plant for $\mathrm{G}_{1}, \mathrm{G}_{2}, \mathrm{G}_{3}$ and $\mathrm{G}_{4}$ respectively. RASI 134 showed highest amount TIR with value of $110.0{ }^{\circ} \mathrm{C}$ day $\mathrm{MJ} /$ plant as compared to $\mathrm{H} 1098$ and HD123.Thermal interception rate of cotton crop sown on $G_{1}$ was higher as compared to $G_{2}, G_{3}$ and $G_{4}$ sown crops due to highest leaf area index produced by first sown crop. Radiation indices (IPAR and thermal interception rate) were higher in first growing environment as compared to other growing environments. This might be due to higher leaf area index recorded in first growing environment than that of others. IPAR and TIR were highest in RASI 134 because of maximum LAI produced by this cultivar.

\section{Efficiency of energy conversion into dry matter}

Thermal use efficiency (TUE) for dry matter production at various phenophases under different growing environments was presented in table 2. Significantly highest TUE was found in G1 followed by G2, G3 and G4, at all phenophases. Among the varieties, RASI 134 showed significantly higher TUE at all the phenophases followed by H 1098 and HD 123. TUE value was highest at $50 \%$ boll opening stage in all the treatments; decrease in TUE with delay in sowing was due to fact that delayed sowing of cotton crop led to early reproductive phase.

Phenophases wise variations in radiation use efficiency for biomass production of cotton 
varieties of four growing environments has been presented in table 3 . Cotton crop sown on $2^{\text {nd }}$ week of April $\left(\mathrm{G}_{1}\right)$ was most efficient in PAR utilization as comparison to crop sown on $4^{\text {th }}$ week of April $\left(\mathrm{G}_{2}\right), 2^{\text {nd }}$ week of May $\left(\mathrm{G}_{3}\right)$ and $1^{\text {st }}$ week of June $\left(\mathrm{G}_{4}\right)$. RASI 134 showed higher RUE followed by H 1098 and HD 123 at all stages.

Table.1 Optical characteristics of cotton varieties under different growing environments

\begin{tabular}{|c|c|c|c|}
\hline Absorption (\%) & Transmission (\%) & Reflection (\%) & Treatments \\
\hline \multicolumn{5}{|c|}{ Time of Sowing } \\
\hline 83.0 & 11.5 & 5.5 & $\mathbf{2}^{\text {nd }}$ week April \\
\hline 81.1 & 11.7 & 6.8 & $\mathbf{4}^{\text {th }}$ week April \\
\hline 78.5 & 14.5 & 7.0 & $\mathbf{2}^{\text {nd }}$ week May \\
\hline 72.3 & 20.2 & 7.5 & $\mathbf{1}^{\text {st }}$ week June \\
\hline \multicolumn{5}{|c|}{ Varieties } \\
\hline 79.9 & 14.7 & 5.4 & HD 123 \\
\hline 83.6 & 10.4 & 6.0 & H 1098 \\
\hline 88.4 & 6.5 & 5.1 & RASI 134 \\
\hline
\end{tabular}

Table.2 Thermal use efficiency of cotton at different phenophases under growing environments and varieties

\begin{tabular}{|c|c|c|c|c|c|}
\hline \multicolumn{5}{|c|}{ Thermal use efficiency $\left(\mathrm{g} / \mathrm{m}^{2} /{ }^{\circ} \mathrm{C}\right.$ day $)$} & \multirow[b]{2}{*}{ Treatments } \\
\hline $\begin{array}{l}50 \% \text { boll } \\
\text { opening }\end{array}$ & $\begin{array}{c}\mathbf{5 0 \%} \text { boll } \\
\text { Formation }\end{array}$ & $\begin{array}{c}\mathbf{5 0 \%} \\
\text { flowering }\end{array}$ & $\begin{array}{l}50 \% \text { square } \\
\text { formation }\end{array}$ & $\begin{array}{c}\text { Vegetative } \\
\text { phase }\end{array}$ & \\
\hline 0.56 & 0.55 & 0.35 & 0.12 & 0.07 & $\begin{array}{c}2^{\text {nd }} \text { week } \\
\text { April }\end{array}$ \\
\hline 0.50 & 0.49 & 0.32 & 0.10 & 0.06 & $\begin{array}{c}4^{\text {th }} \text { week } \\
\text { April }\end{array}$ \\
\hline 0.42 & 0.38 & 0.26 & 0.12 & 0.07 & $\begin{array}{c}2^{\text {nd }} \text { week } \\
\text { May }\end{array}$ \\
\hline 0.35 & 0.33 & 0.24 & 0.10 & 0.06 & $\begin{array}{c}1^{\text {st week }} \\
\text { June }\end{array}$ \\
\hline 0.06 & 0.03 & 0.02 & 0.01 & 0.01 & CD at $5 \%$ \\
\hline & & & & & Varieties \\
\hline 0.41 & 0.40 & 0.25 & 0.08 & 0.06 & HD 123 \\
\hline 0.47 & 0.43 & 0.29 & 0.10 & 0.07 & Н 1098 \\
\hline 0.50 & 0.49 & 0.33 & 0.15 & 0.08 & RASI 134 \\
\hline 0.05 & 0.02 & 0.02 & 0.01 & 0.01 & CD at $5 \%$ \\
\hline
\end{tabular}


Table.3 Radiation use efficiency of cotton at various phenophases under different growing environments and varieties

\begin{tabular}{|c|c|c|c|c|c|}
\hline \multicolumn{5}{|c|}{ Radiation use efficiency (g/MJ) } & \multirow[b]{2}{*}{ Treatment } \\
\hline $\begin{array}{l}50 \% \text { boll } \\
\text { opening }\end{array}$ & $\begin{array}{l}50 \% \text { boll } \\
\text { formation }\end{array}$ & $\begin{array}{c}50 \% \\
\text { flowering } \\
\end{array}$ & $\begin{array}{c}50 \% \text { square } \\
\text { formation }\end{array}$ & $\begin{array}{c}\text { Vegetative } \\
\text { phase } \\
\end{array}$ & \\
\hline 1.15 & 1.06 & 0.76 & 0.34 & 0.26 & $\begin{array}{c}2^{\text {nd }} \text { week } \\
\text { April }\end{array}$ \\
\hline 1.05 & 1.03 & 0.70 & 0.27 & 0.18 & $\begin{array}{c}4^{\text {th }} \text { week } \\
\text { April }\end{array}$ \\
\hline 0.90 & 0.78 & 0.58 & 0.30 & 0.28 & $\begin{array}{c}2^{\text {nd }} \text { week } \\
\text { May }\end{array}$ \\
\hline 0.78 & 0.69 & 0.54 & 0.31 & 0.27 & $\begin{array}{c}1^{\text {st }} \text { week } \\
\text { June }\end{array}$ \\
\hline 0.15 & 0.06 & 0.05 & NS & NS & CD at $5 \%$ \\
\hline & & & & & Varieties \\
\hline 0.89 & 0.82 & 0.56 & 0.21 & 0.24 & HD 123 \\
\hline 0.99 & 0.89 & 0.64 & 0.29 & 0.20 & H 1098 \\
\hline 1.03 & 0.96 & 0.73 & 0.41 & 0.30 & RASI 134 \\
\hline NS & 0.05 & 0.04 & 0.11 & 0.04 & CD at $5 \%$ \\
\hline
\end{tabular}

Fig.1 Heat units consumed by cotton at various phenophases under different growing environments and varieties
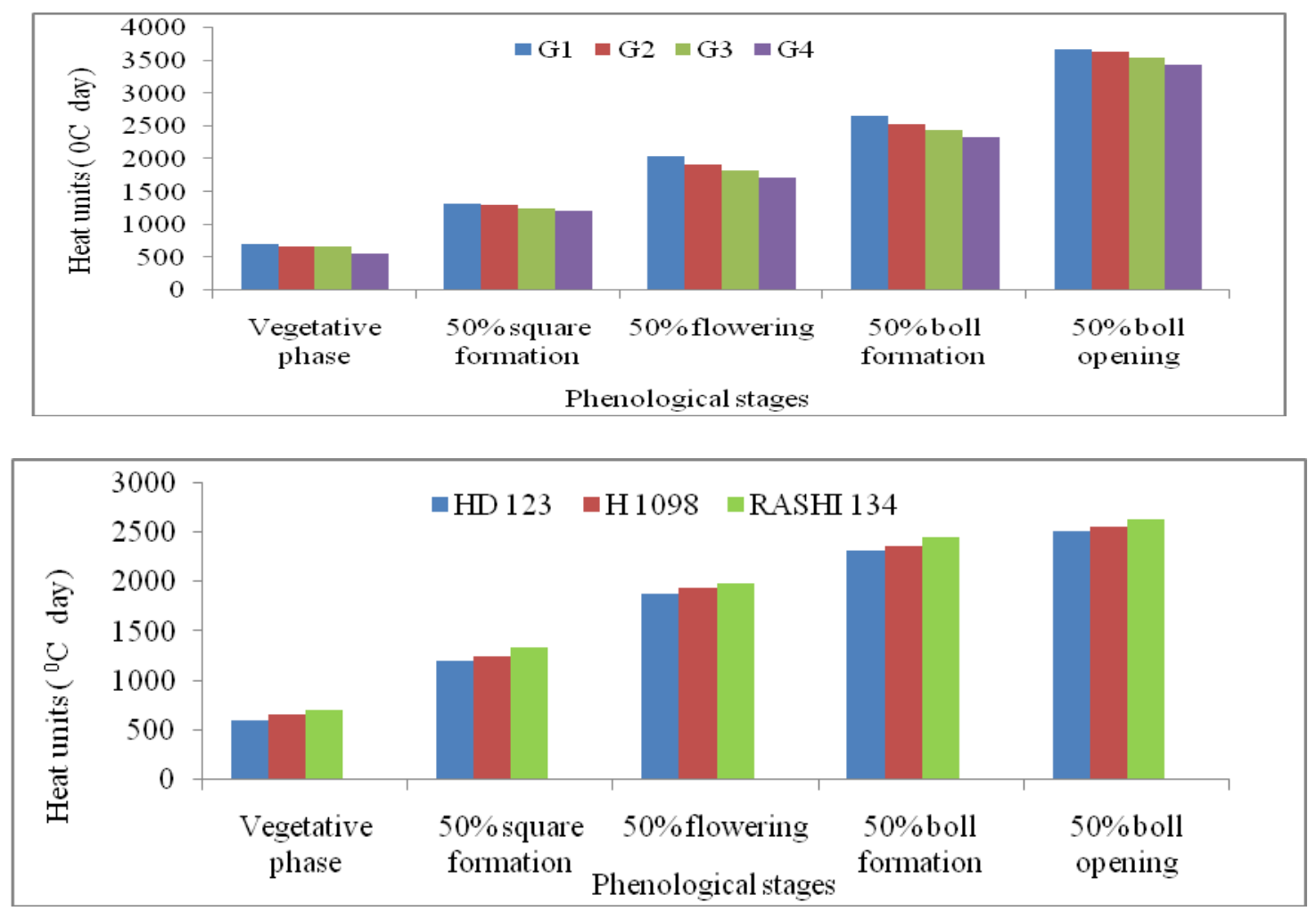
Fig.2 Heliothermal unit's requirement of cotton at various phenophases under different growing environments and varieties
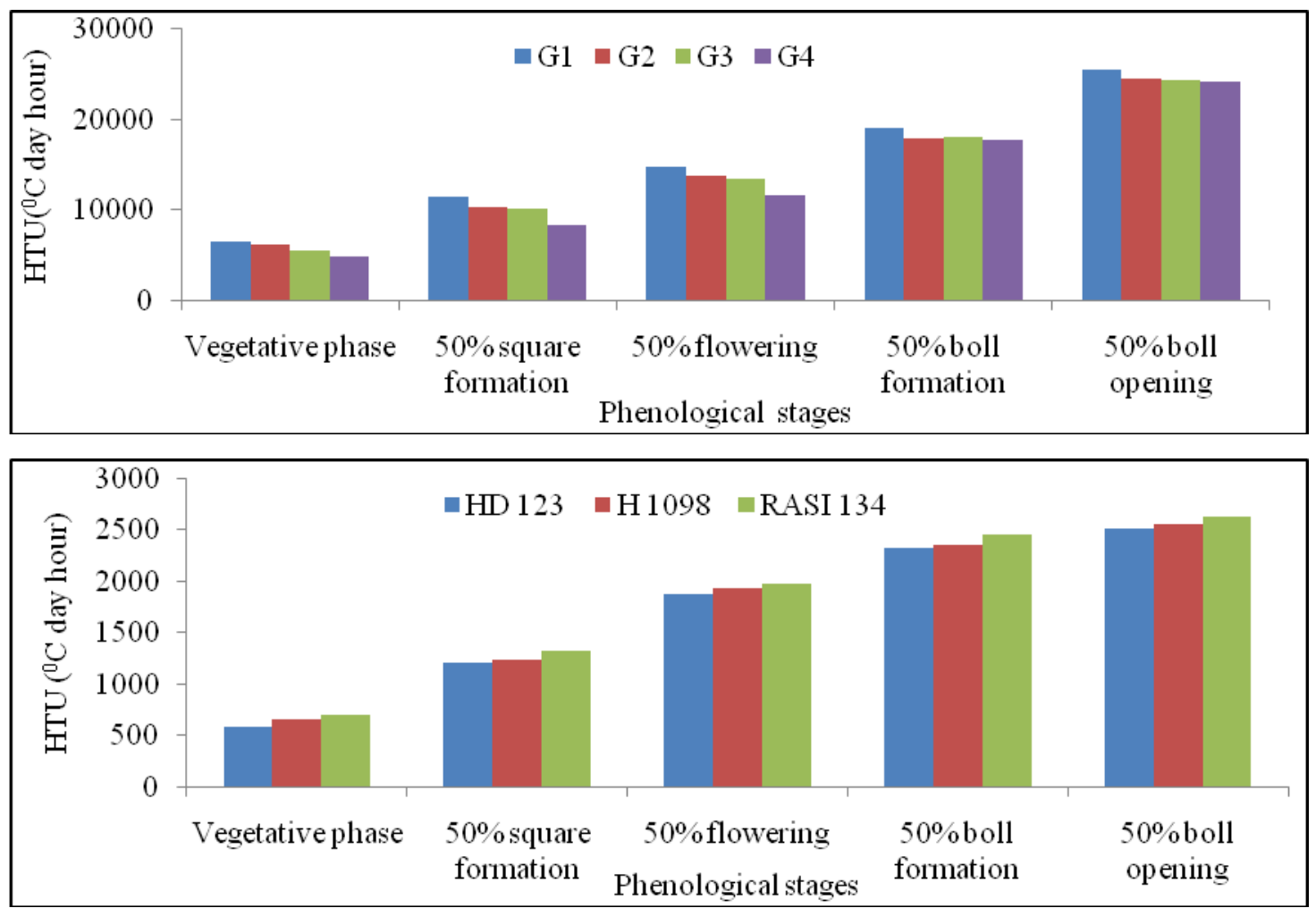

Fig.3 Photothermal unit requirement of cotton at various phenophases under different growing environments and varieties
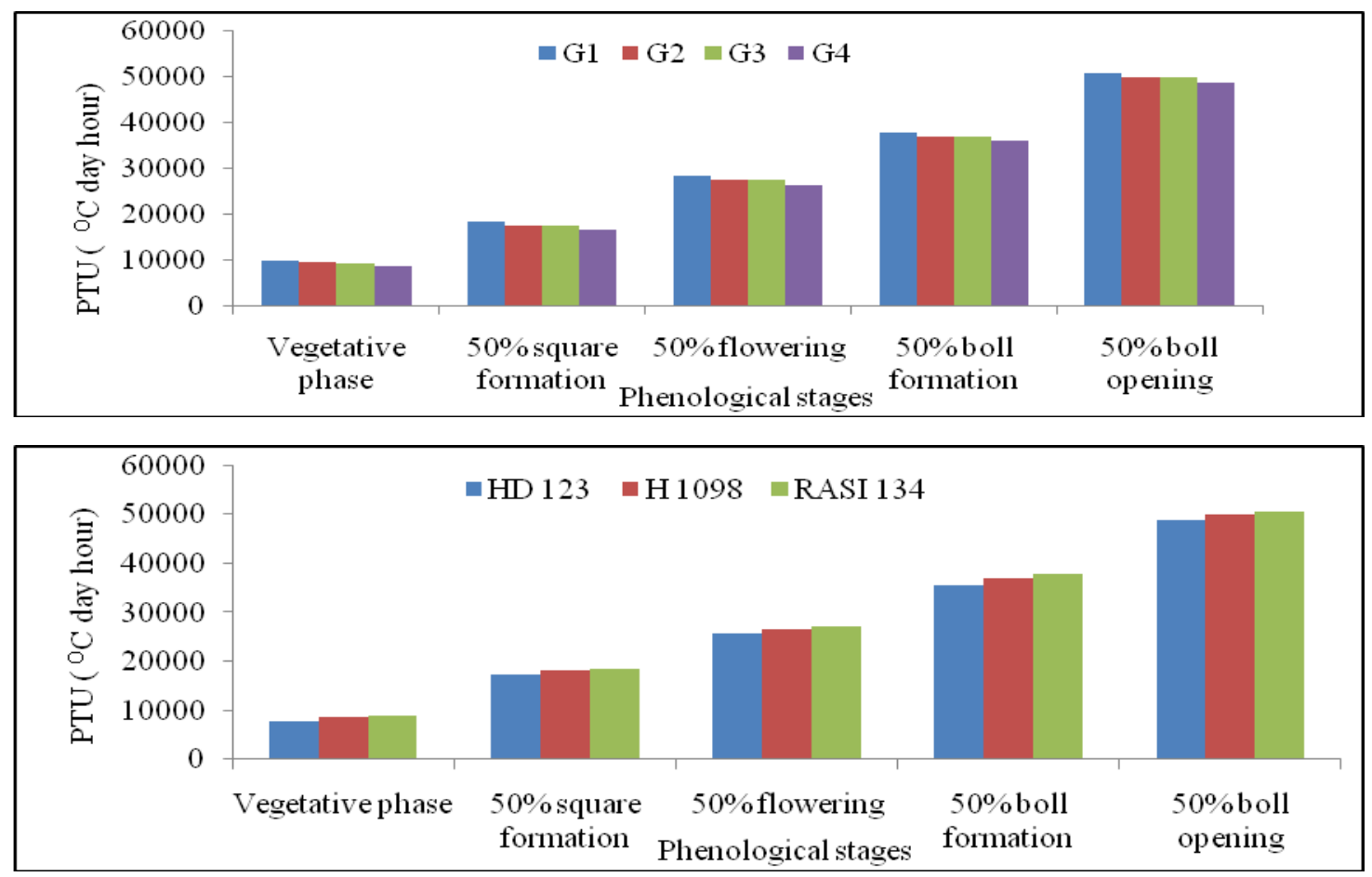
Fig.4 Photosynthetically active radiation intercepted by cotton at various phenophases under different growing environments and varieties
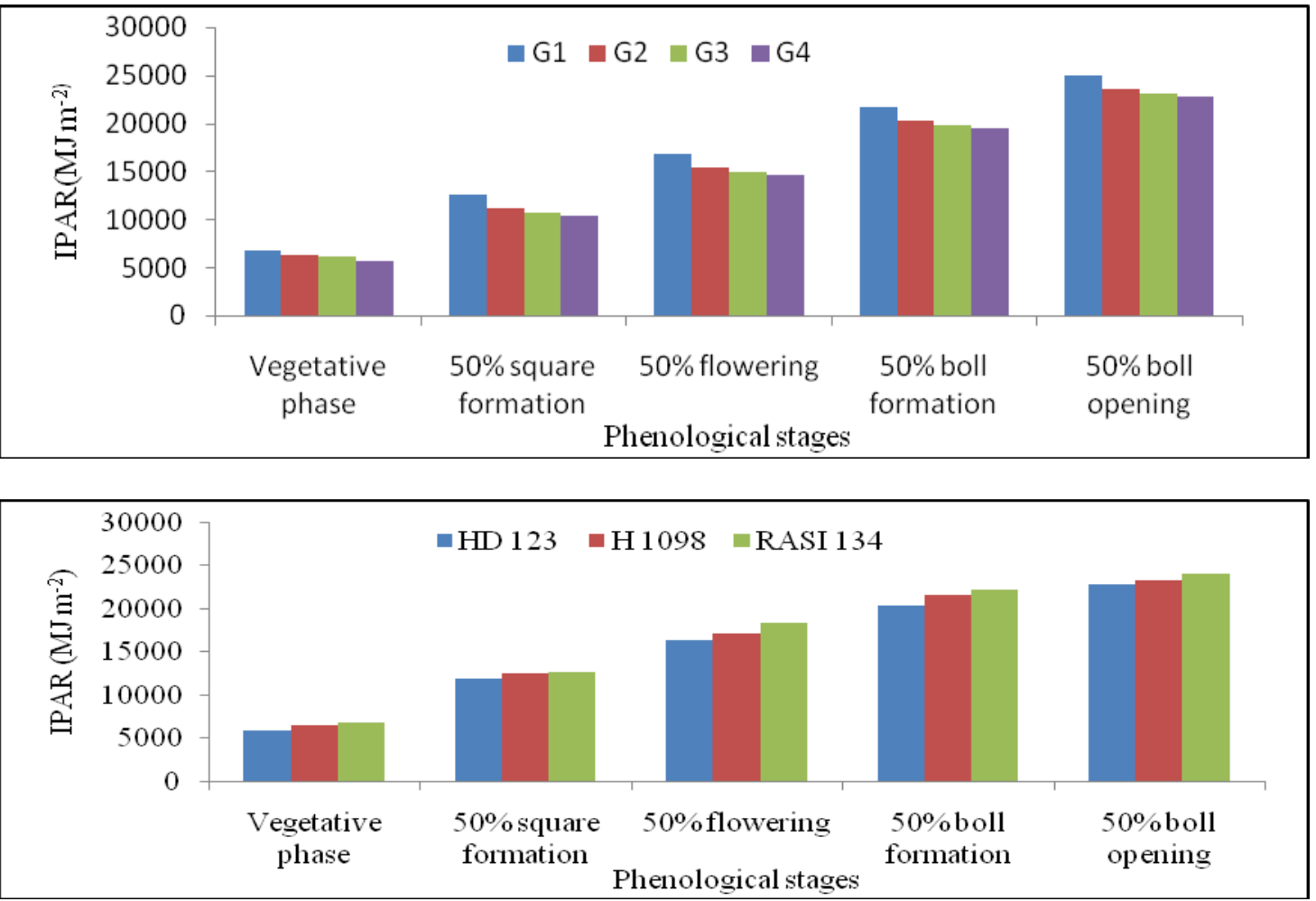

Fig.5 Thermal interception rate of cotton at various phenophases under different growing environments and varieties
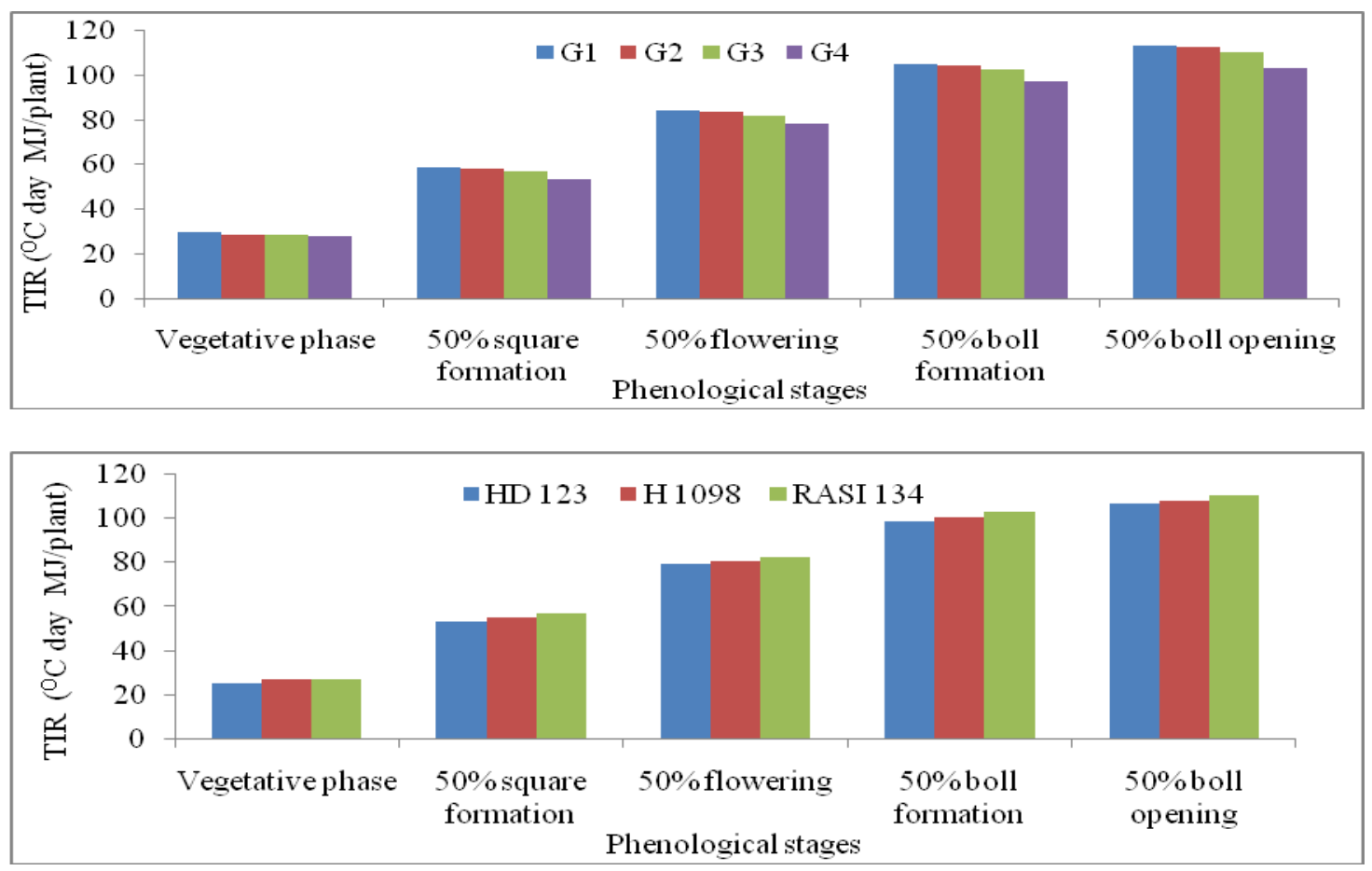
Highest RUE in earlier sown crop and cultivar RASI134 was due to the maximum PAR absorption and dry matter production, both of which decreased subsequently due to reduction in LAI with delayed sowing. Though amount of PAR received above the canopy was almost same in all treatments, the proportion of intercepted PAR differed because of differential crop cover owing to variation in LAI and varying levels of biomass production in different treatments, implying that RUE also differed. RASI 134 showed higher RUE followed by H 1098 and HD 123 at all stages. The maximum value of RUE for dry matter production was observed at $50 \%$ boll opening stage in all treatments because of maximum LAI recorded at this phenophase, maximum RUE in the earlier sown crop was due to the maximum PAR absorption and dry matter production, both of which decreased subsequently due to reduction in LAI with the delayed sowing.

In conclusion, energy indices requirement and thermal interception rate were higher in $2^{\text {nd }}$ week of April sown crop as compared to $4^{\text {th }}$ week of April, $2^{\text {nd }}$ week of May and $1^{\text {st }}$ week of June at all phenological stages. PAR interception was highest in crop sown during $2^{\text {nd }}$ week of April followed by $4^{\text {th }}$ week of April, $2^{\text {nd }}$ week of May and $1^{\text {st }}$ week of June. RASI134 consumed highest HU, HTU and PTU as compared to H1098 and HD 123.The efficiency of energy utilization for dry matter production was highest in RASI 134 and in $2^{\text {nd }}$ week of April sown crop.

\section{References}

Brodrick, R., Bange, M.P., Milroy, S.P. and Hammer, G.L. 2013. Physiological determinants of high yielding ultranarrow row cotton: Canopy development and radiation use efficiency. Field Crops Res., 148: 8694.

Kaur and Hundal. 2006. Prediction of growth and yield of Brassica species using thermal indices. J. Agrometeorol., 8(2): 179-185.

Monga, R.K., Singh, R., Prakash, V. and Narang, R.S. 2009. Assessment of spectral response of tomato (Lycopersicum esculentum L.) to varying microclimate in Western Ghats conditions. Indian J. Agron., 35(1\&2): 153-158.

Peng, S., Krieg, D.R. and Hicks, S.K. 1989. Cotton Lint yield response to accumulated heat units and soil water supply. Field Crops Res., 19: 253-262.

Singh, R. 1999. Crop weather studies in mustard under different environments. Ph.D. Thesis., CCS HAU, Hisar.

Singh, S., Butter, G.S. and Singh, S. 2007. Heat use efficiency of Bt cotton cultivars in the semi- arid region of Punjab. J. Agrometeorol., 9(1): 122124.

Wrona. A.F., J.C. Banks, K. Hake, K., Lege, M. Patterson, B. Roberts. C.E. Snipes, and J. Supak. 1996. Achieving a clean finish. Cotton Phyiol. Today, 7(6): 2531.

\section{How to cite this article:}

Premdeep, Ram Niwas, M.L. Khichar, Abhilash and Abhijeet Sharma. 2017. Quantification of Energy Indices Requirement of Cotton Varieties under Different Growing Environments. Int.J.Curr.Microbiol.App.Sci. 6(3): 809-817. doi: https://doi.org/10.20546/ijcmas.2017.603.095 